\title{
CHLOROQUINE IN RHEUMATOID ARTHRITIS A DOUBLE BLINDFOLD TRIAL OF TREATMENT FOR ONE YEAR
}

BY

\author{
A. FREEDMAN AND V. L. STEINBERG \\ London Hospital
}

Since the preliminary report on the use of mepacrine in the treatment of rheumatoid arthritis (Freedman and Bach, 1952), there has been a gradual appreciation of the value of 4-amino quinolone compounds for this condition. Many papers have appeared (Forestier and Certonciny, 1954; Scherbel, Schuchter, and Harrison, 1957; Erlendsson, 1958; Fuld and Horwich, 1958), but controlled trials have been few. The first (Freedman, 1956) dealt with 66 patients each observed for a period of 16 weeks. The finding that the chloroquine-treated patients did better than the controls was confirmed by trials undertaken by Rinehart, Rosenbaum, and Hopkins (1957), Cohen and Calkins (1958), and Kuipers (1959), in none of which was the period of comparison longer than 26 weeks. Bagnall (1957), convinced of the value of these drugs, abandoned his intention to conduct a controlled trial and published his findings of 4 years' treatment of patients, the longest series yet reported. With one equivocal exception (La Tona and Norcross, 1959), there has been widespread approbation by all authors for these compounds. The present report deals with observations in a double blindfold trial begun in 1956 in a group of patients each of whom was treated for a period of one year.

\section{Method}

Subjects.-Patients were drawn from those attending the Department of Physical Medicine at the London Hospital, those under the care of one of us at Hackney Hospital, and those from the Department of Physical Medicine at Chase Farm Hospital, Enfield.

Diagnostic Criteria.-Patients with rheumatoid type of arthritis with active inflammation of at least four joints and a raised erythrocyte sedimentation rate were admitted irrespective of the duration of the disease or the result of the sheep-cell agglutination test. These patients all satisfied the criteria as having definite rheumatoid arthritis according to the classification of the American Rheumatism Association (Ropes, Bennett, Cobb, Jacox, and Jessar, 1957).

Patients ill enough to be admitted to hospital were not accepted into the trial, and anyone within the trial was withdrawn if the condition so deteriorated as to warrant admission to hospital.

Treatment.-During the trial period all patients received eight 5-gr. tablets of enteric-coated aspirin daily, and if they were anaemic oral iron was also prescribed. The patients also received either chloroquine or dummy tablets of identical appearance, the physician not knowing which kind the patient was having throughout the trial. These tablets were prescribed according to the serial number given to the patient as each was admitted into the trial. A list of these numbers divided randomly into two groups, $P$ and $Q$, was held by the pharmacist, who dispensed either $P$ or $Q$ tablets according to the serial number. The dispenser did not know which was the active preparation. Those patients who were receiving the active preparation were in fact taking chloroquine sulphate $200 \mathrm{mg}$. twice daily. In a few cases in both groups side-effects occurred; these were considered to be toxic effects and a reduction of dosage to one and a half tablets daily was made. Appropriate splinting and physiotherapy were also prescribed.

Assessment.-The patients were examined by one of us at a special clinic held for this purpose on a separate afternoon. At each visit they were asked specific questions concerning their symptoms and their need for analgesics other than those routinely prescribed, and about any change in their self-care and ability to work.

Special note was made of their colour, and the presence of oedema, nodules, lymph-glands, and rashes. The temporo-mandibular, clavicular, and manubrial joints and the spine as well as the limb joints were separately examined.

Joint tenderness was graded I, II, or III (I representing tenderness, II wincing, and III withdrawal of the affected 
part). The sum of these tenderness figures was then recorded as total tenderness.

Strength of grip was measured on a mercury sphygmomanometer by the patient exerting as much pressure as possible on the folded cuff distended to a pressure of $30 \mathrm{~mm}$. Hg. The mean of the pressures for the grip of the right and left hands was recorded as the strength of grip.

The time taken to walk 25 yards was recorded as the walking-time.

The dexterity of the hands was measured by recording the time taken to insert a lace in and out of the holes on one side of a boot.

The patients were assessed at intervals of 2 to 6 weeks. At each visit they were weighed and blood was taken for haemoglobin and erythrocyte sedimentation rate tests.

Blood for sheep-cell agglutination tests was taken at the beginning and the end of the year, as were $x$-rays of the hands and feet.

At the end of the trial these records provided figures expressing the degree of joint inflammation and joint function, and data from which subjective and objective clinical assessments could be made.

\section{Material}

There were 53 patients in the chloroquine group and 54 in the control group entering the trial. The ages and sex distribution (Table I) were similar in both groups, but Table II shows that the chloroquine group happened to contain an excess of patients with disease of less than one year's duration (ten against five) and a deficiency of those with more than 5 years' duration (thirteen against twenty).

\section{Withdrawals}

Three patients, subsequently ascertained as belonging to the control group, deteriorated so much that they had to be taken out of the trial.

One patient on chloroquine informed us that he was not attending further as he was fully recovered.

"Toxic" effects were sufficiently severe to cause four

\section{TABLE II}

DURATION OF DISEASE (YEARS) AT ENTRY AND ON COMPLETION OF TRIAL

\begin{tabular}{|c|c|c|c|c|c|}
\hline \multicolumn{2}{|c|}{ Series of Patients } & \multicolumn{2}{|c|}{ At Entry } & \multicolumn{2}{|c|}{ On Completion } \\
\hline \multicolumn{2}{|c|}{ Therapy } & Control & $\begin{array}{l}\text { Chloro- } \\
\text { quine }\end{array}$ & Control & $\begin{array}{c}\text { Chloro } \\
\text { quine }\end{array}$ \\
\hline \multirow{4}{*}{$\begin{array}{c}\text { Duration of } \\
\text { Disease } \\
(y r s)\end{array}$} & Less than 1 & 5 & 10 & 4 & 9 \\
\hline & $1-4$ & 29 & 30 & 21 & 22 \\
\hline & $5-9$ & 10 & 8 & 9 & 6 \\
\hline & 10 & 10 & 5 & 6 & 5 \\
\hline \multicolumn{2}{|c|}{ Total No. of Patients. } & 54 & 53 & 40 & 42 \\
\hline
\end{tabular}

control cases and five chloroquine cases to discontinue $\underset{0}{-\frac{1}{4}}$ treatment.

For various reasons including those mentioned abovei (Table III, opposite), altogether fourteen controls and $\vec{\omega}$ eleven chloroquine patients did not complete the trial.o There remained for comparison 42 patients in the chloroquine group and forty patients in the $\operatorname{control}_{\mathcal{C}}$ group. Table II shows an excess of patients in thee chloroquine group who had disease of less than one year's duration (nine as against four).

\section{Results}

Joint Tenderness (Table IV, opposite).-Only three patients were entirely free of joint tenderness at theo end of the year and all had received chloroquine. Thirteen of the control patients had widespreado tenderness at the end of the year, whereas only fouro chloroquine patients had similar lack of improve- $\stackrel{\mathbb{Q}}{\varrho}$ ment. The average figures for total tenderness were $\overrightarrow{0}$ 28.4 in the control group and 27.0 in the chloro-3 quine group falling to $25 \cdot 4$ and $13 \cdot 5$ respectively by the end of the year. The degree of improvement in? the chloroquine group was statistically significanto $(t=5.91 ; p<0.001)$.

TABLE I

AGE AND SEX DISTRIBUTION AT ENTRY AND ON COMPLETION OF TRIAL

\begin{tabular}{|c|c|c|c|c|c|c|c|c|c|c|c|c|c|}
\hline \multicolumn{2}{|c|}{ Series of Patients } & \multicolumn{6}{|c|}{ At Entry } & \multicolumn{6}{|c|}{ On Completion } \\
\hline \multicolumn{2}{|l|}{ Therapy } & \multicolumn{3}{|c|}{ Control } & \multicolumn{3}{|c|}{ Chloroquine } & \multicolumn{3}{|c|}{ Control } & \multicolumn{3}{|c|}{ Chloroquine } \\
\hline Sex & . . . & Male & Female & Total & Male & Female & Total & Male & Female & Total & Male & Female & Total \\
\hline \multirow{5}{*}{$\underset{\text { (yrs) }}{\text { Age }}$} & -39 & 1 & 6 & 7 & 0 & 8 & 8 & 1 & 5 & 6 & 0 & 7 & 7 \\
\hline & $40-49$ & 4 & 15 & 19 & 3 & 12 & 15 & 4 & 12 & 16 & 2 & 11 & 13 \\
\hline & $50-59$ & 5 & 14 & 19 & 6 & 15 & 21 & 4 & 9 & 13 & 5 & 10 & 15 \\
\hline & $60-$ & 3 & 6 & 9 & 1 & 8 & 9 & 2 & 3 & 5 & 0 & 7 & 7 \\
\hline & All Ages & 13 & 41 & 54 & 10 & 43 & 53 & 11 & 29 & 40 & 7 & 35 & 42 \\
\hline
\end{tabular}


TABLE III

REASONS FOR WITHDRAWALS FROM TRIAL

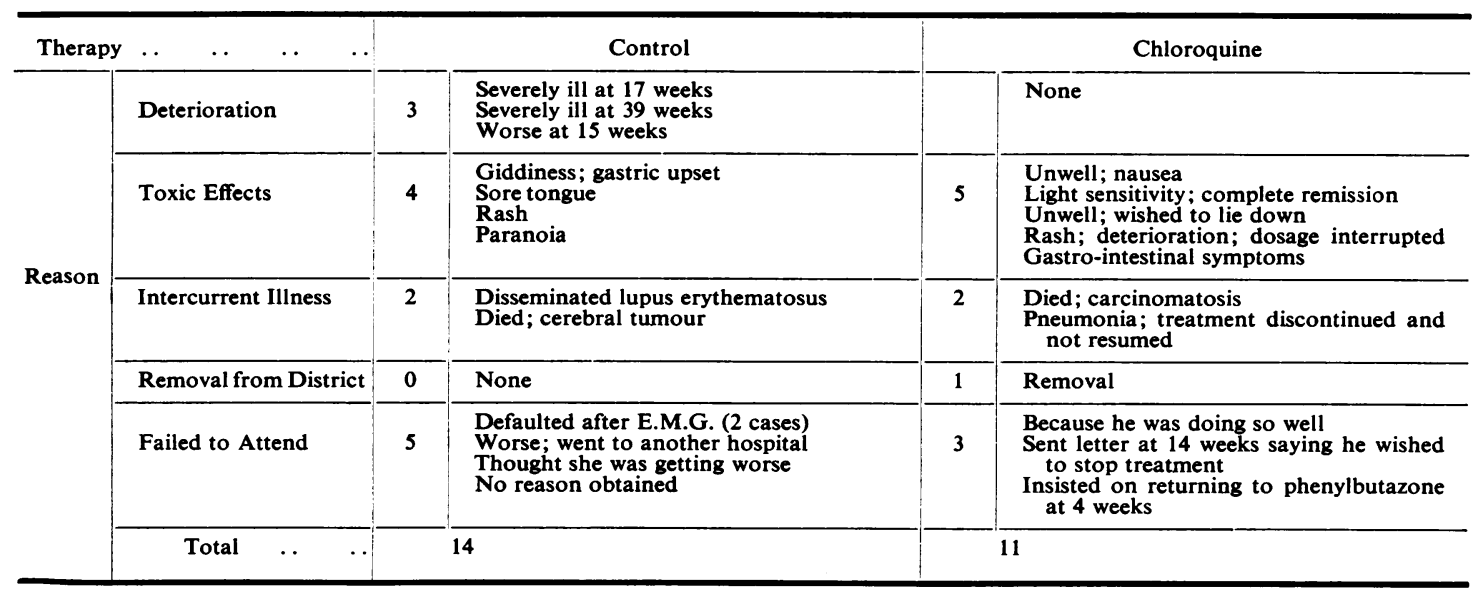

TABLE IV

NUMBER OF PATIENTS WITH GIVEN TENDERNESS AT END OF COURSE OF TREATMENT RELATED TO INITIAL RANGE OF TENDERNESS

\begin{tabular}{|c|c|c|c|c|c|c|c|}
\hline \multirow{2}{*}{$\begin{array}{c}\text { Range } \\
\text { of } \\
\text { Initial } \\
\text { Tender- } \\
\text { ness }\end{array}$} & \multirow[t]{2}{*}{ Therapy } & \multirow{2}{*}{$\begin{array}{c}\text { No. } \\
\text { of } \\
\text { Patients }\end{array}$} & \multicolumn{5}{|c|}{$\begin{array}{c}\text { Range of Joint Tenderness } \\
\text { at End of Course }\end{array}$} \\
\hline & & & 0 & $1-10$ & $11-20$ & $21-30$ & $31+$ \\
\hline \multirow{2}{*}{$1-10$} & Control & 2 & - & - & - & 2 & - \\
\hline & Chloroquine.. & 3 & 1 & 2 & - & 一 & 一 \\
\hline \multirow{2}{*}{$11-20$} & Control & 13 & - & 3 & 8 & 2 & 一 \\
\hline & Chloroquine.. & 11 & 0 & 6 & 4 & 1 & 一 \\
\hline \multirow{2}{*}{$21-30$} & Control & 13 & - & 1 & 8 & 1 & 3 \\
\hline & Chloroquine.. & 13 & 1 & 6 & 5 & 0 & 1 \\
\hline \multirow{2}{*}{$31+$} & Control & 12 & 一 & - & 2 & 一 & 10 \\
\hline & Chloroquine.. & 15 & 1 & 5 & 4 & 2 & 3 \\
\hline \multirow{2}{*}{ Total } & Control & 40 & - & 4 & 18 & 5 & 13 \\
\hline & Chloroquine.. & 42 & 3 & 19 & 13 & 3 & 4 \\
\hline
\end{tabular}

\section{Function Tests}

Strength of Grip (Table V).- The mean strength of grip of the forty controls at the start of treatment was $125 \mathrm{~mm} . \mathrm{Hg}$, rising to $128 \mathrm{~mm} . \mathrm{Hg}$ at the end of one year. The figures for the chloroquine group were $124 \mathrm{~mm}$. $\mathrm{Hg}$, rising to $165 \mathrm{~mm}$. $\mathrm{Hg}$. The improvement in those receiving chloroquine was statistically significant $(t=3.915 ; p<0.001)$.

Dexterity (Table VI).-Both groups showed an improvement that was statistically significant (controls $t=3 \cdot 2535 ; p<0.01$. Chloroquine $t=4.06$; $p<0.001$ ).

Walking Time (Table VI).-Here only the chloroquine group showed statistically significant improvement $(t=3.0001 ; p<0.01)$.

Tenderness and Function Score.-This was obtained by awarding:

50 marks if there was no tenderness, i.e. $\left(\frac{100-0}{2}\right)$, 25 if the grip was $200 \mathrm{~mm}$. $\mathrm{Hg}$ or more, i.e. $\left(\frac{200}{8}\right)$, 25 if the walking time was 20 sec., i.e. $\left(\frac{70-20}{2}\right)$, making a possible total of 100 .

TABLE V

CHANGE IN STRENGTH OF GRIP (mm. Hg) BETWEEN BEGINNING AND END OF TREATMENT

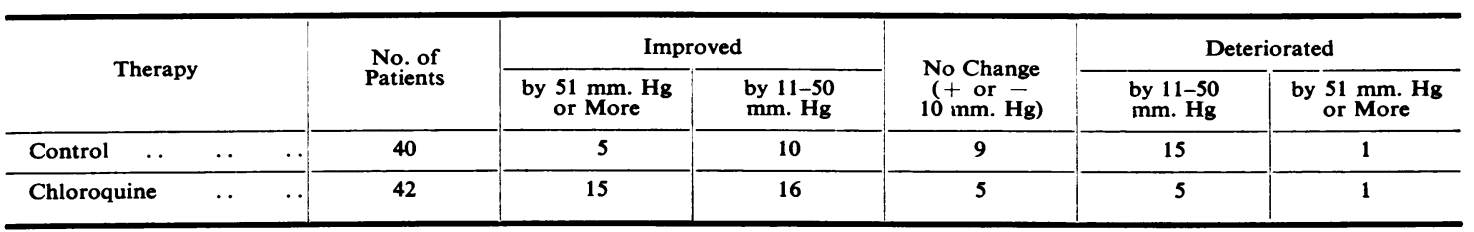


DEXTERITY, WALKING, HAEMOGLOBIN, AND ERYTHROCYTE SEDIMENTATION RATE

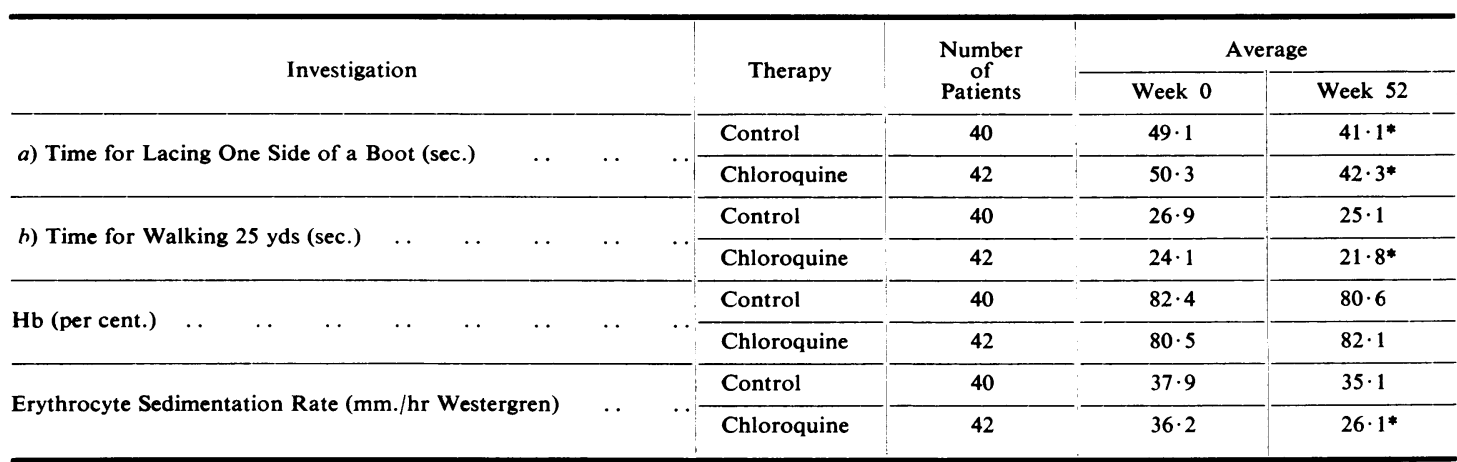

* Improvement statistically significant

For example, if a patient had a total tenderness of 24 , a grip of $160 \mathrm{~mm} . \mathrm{Hg}$, and a walking time of $40 \mathrm{sec}$., he was awarded $\frac{100-24}{2}+\frac{160}{8}+\frac{70-40}{2}$, i.e. a score of 73. The Figure (below) compares the scores at the beginning and end of the year for the control and chloroquine groups. The mean change for the control group was $+2 \cdot 1$, while for the chloroquine group it was $+12 \cdot 2$, which is statistically significant $(t=6 \cdot 987 ; p<0.001)$.

CONTROLS

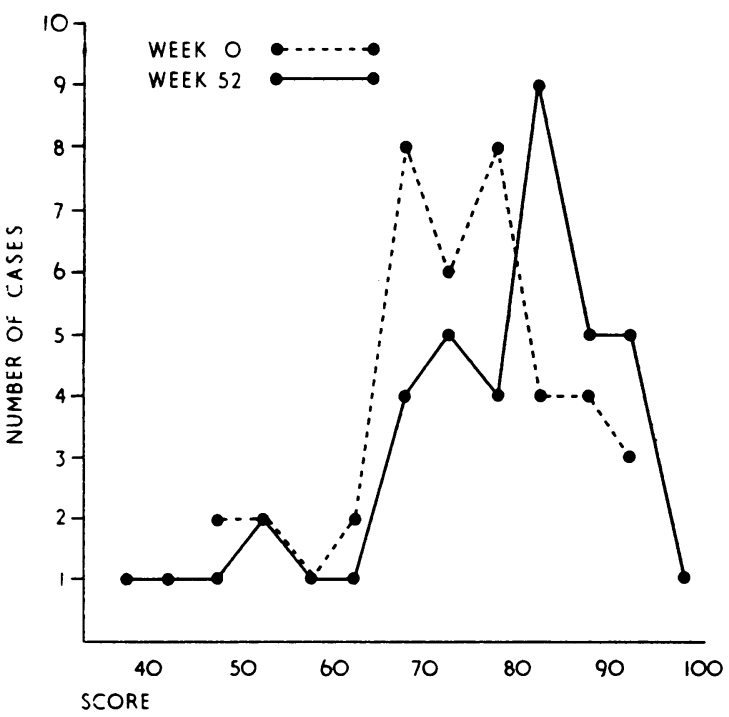

Figure.-
Haemoglobin Levels (Table VI).-There was no significant change in either group.

Erythrocyte Sedimentation Rate (Table VI).--Only the chloroquine group showed a significant im- $\frac{3}{0}$ provement during the year, an average fall of $10 \cdot 1 \stackrel{\mathbb{}}{-}$ $\mathrm{mm}$./hr (Westergren) $(t=3.771 ; p<0.001)$. \ $\vec{\bullet}$

Radiological Changes (Table VII).-The $x$ rays क्ष the hands and feet at the start and at the end of the

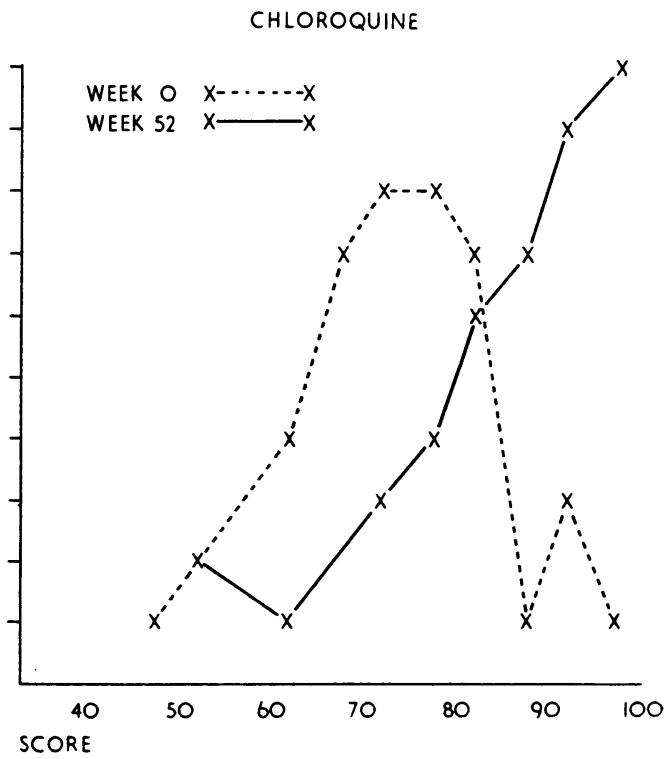


CHLOROQUINE IN RHEUMATOID ARTHRITIS

TABLE VII

RADIOLOGICAL CHANGES IN FILMS OF HANDS AND FEET AT BEGINNING AND END OF ONE YEAR'S TREATMENT

\begin{tabular}{|c|c|c|c|c|c|c|c|c|c|c|c|c|c|}
\hline \multirow{2}{*}{\multicolumn{3}{|c|}{ Therapy }} & \multirow{2}{*}{$\begin{array}{c}\text { No. } \\
\text { of } \\
\text { Patients }\end{array}$} & \multirow{2}{*}{$\begin{array}{c}\text { Time } \\
\text { of } \\
\text { Assessment }\end{array}$} & & & \multicolumn{4}{|c|}{ Grade } & \multicolumn{3}{|c|}{ Change } \\
\hline & & & & & 0 & 1 & 2 & 3 & 4 & Not Done & Worse & $\begin{array}{c}\text { No } \\
\text { Change }\end{array}$ & Better \\
\hline \multirow{2}{*}{ Control .. } & \multirow{2}{*}{$\cdots$} & \multirow{2}{*}{$\cdots$} & \multirow{2}{*}{40} & Week 0 & 3 & 1 & 16 & 10 & 9 & 1 & \multirow{2}{*}{12} & \multirow{2}{*}{27} & \multirow{2}{*}{0} \\
\hline & & & & Week 52 & 1 & 1 & 11 & 16 & 11 & - & & & \\
\hline \multirow{2}{*}{ Chloroquine } & \multirow{2}{*}{$\cdots$} & \multirow{2}{*}{$\cdots$} & \multirow{2}{*}{42} & Week 0 & 5 & 3 & 20 & 9 & 4 & 1 & \multirow{2}{*}{5} & \multirow{2}{*}{31} & \multirow{2}{*}{2} \\
\hline & & & & Week 52 & 2 & 1 & 17 & 15 & 4 & 3 & & & \\
\hline
\end{tabular}

trial were brought together and read by a single observer who had no knowledge of type of treatment given. The gradings were based on the incidence of articular erosions, joint narrowing, and subluxation.

\begin{tabular}{c|l}
\hline Grade & Abnormality \\
\hline 0 & none \\
1 & doubtful \\
2 & slight \\
3 & moderate \\
4 & severe \\
\hline
\end{tabular}

Changes within any particular grade were also recorded, although they might not be sufficient to alter the grading for severity. Improvement with regard to healing of erosions was observed in two chloroquine cases. Undoubted deterioration occurred in twelve of the control cases and five of the chloroquine cases.

Haemagglutination Tests (Table VIII).--Unfortunately, during the period of the trial, the method for carrying out diagnostic agglutination tests for rheumatoid arthritis was undergoing change. The Rose-Waaler sheep-cell agglutination test, the Ball modification of this test, and the Latex-fixation test were used successively and the tests were carried out not at one centre but at the three hospitals which the patients were attending. Table VIII merely summarizes the positive and negative results for what they are worth. The distribution of positive and negative cases was the same in both groups at the beginning of the trial, but at the end of the year the positive cases in the chloroquine group had fallen from 23 to 19 , whereas in the control group they had increased from 23 to 32 . One-third of all the cases at the beginning of the trial showed negative tests; at the end of the year almost half of the chloroquine cases and only one-fifth of the control cases were negative.
TABLE VIII

RESULTS OF HAEMAGGLUTINATION TESTS IN PATIENTS WHO COMPLETED COURSE

\begin{tabular}{c|cc|c|c}
\hline \multirow{3}{*}{ Therapy } & \multirow{2}{*}{ Result of Test } & \multicolumn{2}{|c}{ No. of Cases } \\
\cline { 3 - 5 } & & \multicolumn{2}{|c}{ Week 0 } & Week 52 \\
\cline { 3 - 5 } Control & Positive &. & 23 & 32 \\
& Negative &. & 13 & 8 \\
& Not done &. & 4 & 0 \\
\cline { 2 - 5 } & Total &. & 40 & 40 \\
\hline \multirow{3}{*}{ Chloroquine } & Positive &. & 23 & 19 \\
& Negative &. & 13 & 22 \\
& Not done &. & 6 & 1 \\
\cline { 2 - 5 } & Total &. & 42 & 42 \\
\hline
\end{tabular}

Functional Capacity* and Disease Activity $\dagger$ (Table IX, overleaf).- The gradings were those adopted by Duthie, Thompson, Weir, and Fletcher (1955):

\footnotetext{
* Grade $I=$ Fit for all normal activities

Grade II $=$ Moderate restriction.

Grade III = Marked restriction.

Grade IV = Confined to chair or bed (such cases were excluded from entry to the trial or withdrawn if they deteriorated to this grade).

$\uparrow$ Grade $1=$ Very Active (E.S.R. over $60 \mathrm{~mm} . / \mathrm{hr}$, haemoglobin $<65$ per cent., widespread inflammation).

Grade 2 Moderately Active (E.S.R. 20 to $60 \mathrm{~mm}$. $/ \mathrm{hr}$, haemoglobin 65-85 per cent. several joints involved).

Grade 3 = Inactive (E.S.R. $<20 \mathrm{~mm} . / \mathrm{hr}$, haemoglobin 85 per cent. or over, no joint inflammation).
}

Of all the indices for comparison which we have employed, functional capacity was the only one where there was a significant difference between the control and chloroquine cases, both those who entered the trial and those who remained after discounting withdrawals. This dissimilarity is probably attributable to the longer duration of the disease in the control cases. Functional capacity is dependent on structural change which cannot improve and disease activity which can. With respect to disease activity the two groups were comparable. As shown in Table IX, both in functional capacity and disease activity the chloroquine group made undoubted improvement. 
TABLE IX

FUNCTIONAL CAPACITY AND DISEASE ACTIVITY AT BEGINNING AND END OF ONE YEAR'S TREATMENT

\begin{tabular}{|c|c|c|c|c|c|}
\hline \multirow{2}{*}{ Grade } & & \multicolumn{2}{|c|}{ Control } & \multicolumn{2}{|c|}{ Chloroquine } \\
\hline & & $\begin{array}{c}\text { Week } \\
0\end{array}$ & $\begin{array}{c}\text { Week } \\
52\end{array}$ & $\underset{0}{\text { Week }}$ & $\underset{52}{\text { Week }}$ \\
\hline \multirow{2}{*}{$\begin{array}{c}\text { Functional } \\
\text { Capacity }\end{array}$} & III & $\begin{array}{l}12 \\
12 \\
16\end{array}$ & $\begin{array}{l}16 \\
14 \\
10\end{array}$ & $\begin{array}{r}15 \\
21 \\
6\end{array}$ & $\begin{array}{r}27 \\
11 \\
4\end{array}$ \\
\hline & Total $\ldots$ & 40 & 40 & 42 & 42 \\
\hline \multirow{4}{*}{$\begin{array}{l}\text { Disease } \\
\text { Activity }\end{array}$} & 1 & 1 & 2 & 2 & 2 \\
\hline & 2 & 39 & 36 & 40 & 28 \\
\hline & 3 & 0 & 2 & 0 & 12 \\
\hline & Total $\ldots$ & 40 & 40 & 42 & 42 \\
\hline
\end{tabular}

Assessment of Response to Treatment (Table X).At the end of the trial all the records were reviewed. On the basis of the patient's own replies it was possible to give an assessment of his own view of his improvement or deterioration, while the clinical and laboratory data permitted an objective assessment. Table $X$ shows that about 50 per cent. of the control group thought they had improved but the objective impression was 30 per cent., and definite deterioration had occurred in 25 per cent. On the other hand, of those who received and tolerated chloroquine, 90 per cent. felt that they had improved, and 80 per cent. showed objective improvement, 15 per cent. having had a complete remission. Deterioration occurred in only 5 per cent. of the chloroquine cases.

Toxic Effects.-The side-effects of prolonged chloroquine administration at this dosage include blurred vision, giddiness, nausea, vomiting, diarrhoea, headache, pruritus, and a patchy dry dermatitis. Complaints of this nature were made by patients in both groups and were regarded as toxic effects. 33 out of the 53 patients who started on chloroquine had some such complaint, seven of them having $\frac{2}{3}$ more than one complaint, and 22 of the 54 controls had so-called toxic effects, six of them having more than one complaint. The actual number of such toxic symptoms is shown in Table XI. They were regarded as serious enough to warrant withdrawal from the trial in four of the control group and five of the chloroquine group (Table III).

TABle XI

INCIDENCE OF TOXIC EFFECTS IN ALL PATIENTS WHO EMBARKED ON THE TRIAL

\begin{tabular}{|c|c|c|c|}
\hline \multicolumn{2}{|c|}{ Therapy } & Control & Chloroquine \\
\hline \multirow[t]{2}{*}{ Disturbances } & $\begin{array}{l}\text { Vision } \\
\text { Gastro-intestinal } \\
\text { Skin .. } \\
\text { Nervous system } \\
\text { Other } \quad .\end{array}$ & $\begin{array}{r}4 \\
11 \\
7 \\
13 \\
1\end{array}$ & $\begin{array}{r}15 \\
9 \\
16 \\
9 \\
3\end{array}$ \\
\hline & Total $\ldots$ & in 22 patients & in 33 patients \\
\hline \multicolumn{2}{|c|}{ Patients with no Toxic Effects } & $\begin{array}{c}32 \\
\text { out of } 54\end{array}$ & $\begin{array}{c}20 \\
\text { out of } 53\end{array}$ \\
\hline Withdrawals. & $\ldots$ & 4 & 5 \\
\hline
\end{tabular}

\section{Discussion}

Comparability of Groups before and after Witho drawals.-The random distribution of cases su@g ceeded in providing similarity of both groups witt regard to age and sex distribution, but not fo duration of disease as there were five control cases and ten chloroquine cases with duration of disease of less than one year. The Table indicates that this difference still remained in those who completed the trial. Since such patients are known to do well without treatment, a separate analysis was undertaken of cases with more than 1 year's duration of arthritis. This showed results similar to those of the groups as a whole.

Results.-If one accepts the groups as comparable then the results are favourable to chloroquine.

TABle $\mathbf{X}$

SUBJECTIVE AND OBJECTIVE IMPRESSIONS OF RESPONSE TO TREATMENT

\begin{tabular}{|c|c|c|c|c|c|c|c|c|c|}
\hline \multirow{3}{*}{ Impression } & \multirow{3}{*}{ Therapy } & \multirow{3}{*}{$\begin{array}{c}\text { Number } \\
\text { of } \\
\text { Patients }\end{array}$} & \multicolumn{7}{|c|}{ Grade of Response to Treatment } \\
\hline & & & \multicolumn{3}{|c|}{ Improved } & \multirow{2}{*}{ No Change } & \multicolumn{3}{|c|}{ Worse } \\
\hline & & & Much & Moderately & Slightly & & Slightly & Moderately & Much \\
\hline \multirow{2}{*}{ Subjective } & Control & 40 & 1 & 11 & 8 & 11 & 9 & 0 & 0 \\
\hline & Chloroquine & 42 & 12 & 18 & 8 & 1 & 1 & 2 & 0 \\
\hline \multirow{2}{*}{ Objective } & Control & 40 & 1 & 7 & 6 & 14 & 10 & 2 & 0 \\
\hline & Chloroquine & 42 & $7 *$ & 20 & 6 & 7 & 0 & 2 & 0 \\
\hline
\end{tabular}

* Complete remission. 
Though a few patients showed little or no response, most of the chloroquine group undoubtedly enjoyed a lessening of joint inflammation and improvement in function. The tests used to demonstrate this did, it must be admitted, depend on the examiner's assessment and the co-operation of the patient. However, the erythrocyte sedimentation rate was an entirely objective estimation and this too showed a significant improvement in the chloroquine group. The changes in technique in the haemagglutination tests were unfortunate, but we feel that the results should not be dismissed, first because these changes would have affected both groups equally, and secondly because the changes of method made the tests more sensitive, so that more positive results would be detected at the final examination. Confirmation of this very favourable response to chloroquine is of some importance, since it contrasts with the increase in haemagglutination titres that occurred in patients receiving prednisone (Medical Research Council and Nuffield Foundation, 1959).

The differences observed in the progression of $x$-ray changes in the two groups should not perhaps be used as an argument in favour of chloroquine. A longer period of observation and a more detailed assessment of individual joints should be undertaken to provide a system of scoring for use by the statistician.

Safety of Chloroquine.-Side-effects of various kinds occurred in 33 cases (62.5 per cent.), but the fact that similar symptoms also occurred in 22 (40 per cent.) of the control cases shows that it should not be assumed that the drug is alone responsible. A small reduction in dosage may enable the patient to tolerate the drug and yet have worthwhile benefit. In this investigation, with a maximum dosage of $400 \mathrm{mg}$. chloroquine sulphate daily for one year, no irreversible toxic effect occurred. Experience outside this trial (Hobbs, Sorsby, and Freedman, 1959), however, has revealed one serious side-effect, a retinopathy occurring in a few patients who had received more than 2 years of continuous treatment with this group of drugs. It may therefore be advisable to limit the period of treatment to 2 years.

\section{Summary}

A double blindfold trial is reported in which patients with rheumatoid arthritis received either chloroquine or dummy tablets. 107 patients entered the trial at the three centres which participated; 53 received the drug and 54 the placebo. The dose of chloroquine sulphate was $400 \mathrm{mg}$. daily. All patients also recieved $40 \mathrm{gr}$. aspirin daily and appropriate physiotherapy.
There were 25 withdrawals from the trial for various reasons, fourteen control cases and eleven chloroquine cases. Toxic effects were responsible for five withdrawals in the chloroquine group and four in the control group. Three of the control cases so deteriorated that they had to be withdrawn from the trial.

There remained forty patients in the control group and 42 in the chloroquine group who completed 1 year of treatment.

The patients who received and tolerated the chloroquine showed statistically significant improvement with respect to indices of clinical assessment and erythrocyte sedimentation rate. No change was observed in the average haemoglobin estimations. Haemagglutination tests were done by different methods over the period of the trial, but the changes noted indicated marked improvement in the chloroquine group. The $x$-ray changes were not submitted to statistical analysis but tended to show less progression in the chloroquine group than in the control group.

Definite general improvement occurred in 30 per cent. of the forty controls and 80 per cent. of the 42 patients on chloroquine who completed the year of treatment. Excluding defaulters, substantial improvement occurred in 60 per cent. of the patients who began treatment with chloroquine. Deterioration occurred in 25 per cent. of the control cases, and in only 5 per cent. of the chloroquine cases. Chloroquine sulphate in this dosage given for one year proved to be perfectly safe.

We wish to thank Dr. W.S. Tegner who kindly allowed us to treat his patients at a Special Clinic at the London Hospital and for his comments on this paper. Our thanks are also due to Dr. R. M. Mason for allowing us to treat some of his patients at Chase Farm Hospital, Enfield. We also thank Miss G. Orme of the Department of Physical Medicine, at the London Hospital, Mrs. Yandell at Chase Farm Hospital, and Sister I. Rowatt at Hackney Hospital for their help in running the Special Clinics.

We thank Dr. J. T. Boyd for his preparation of the trial and his advice with results. Messrs. May and Baker Ltd. kindly prepared the tablets, and Mr. C. H. Sykes and Mr. R. Linklater, Chief Dispensers at the London and Hackney Hospitals respectively, gave us valuable co-operation.

We also wish to thank J. Myson, Medical Records Officer, London Hospital, for his very great assistance in the preparation of the data.

\section{REFERENCES}

Bagnall, A. W. (1957). Canad. med. Ass. J., 77, 182.

Cohen, A. S., and Calkins, E. (1958). Arthr. and Rheum., 1, 297.

Duthie, J. J. R., Thompson, M., Weir, M. M., and Fletcher, W. B. (1955). Ann. rheum. Dis., 14, 133 .

Erlendsson, F. (1958). Ugeskr. Laeg., 120, 800.

Forestier, J., and Certonciny, A. (1954). Rev. Rhum., 21, 395. 
Freedman, A. (1956). Ann. rheum. Dis., 15, 251.

and Bach, F (1952). Lancet, 2, 321 .

Fuld, H., and Horwich, L. (1958). Brit. med. J., 2, 1199.

Hobbs, H. E. Sorsby, A., and Freedman, A. (1959). Lancet, 2, 478

Kuipers, R. K. W. (1959). Z. Rheumaforsch., 18, 197.

La Tona, S. R., and Norcross, B. M. (1959). Arch. inter-amer. Rheum., 2, 595.

M.R.C. and Nuffield Foundation Joint Committee (1959). Ann. rheum. Dis., 18, 173.

Rinehart, R. E., Rosenbaum, E. E., and Hopkins, C. E. (1957). Northwest Med., 56, 703.

Ropes, M. W., Bennett, G. A., Cobb, S., Jacox, R., and Jessar, R. A (1957). Ann. rheum. Dis., 16, 118.

Scherbel, A. L., Schuchter, S. L., and Harrison, J. W. (1957). Cleveland Clin. Quart., 24, 98.

Chloroquine dans l'arthrite rhumatismale.-Un essai à "double feinte" de traitement pendant un an

\section{RÉSUMÉ}

On décrit les résultats d'un essai à "double feinte" (double blind) où les malades atteints d'arthrite rhumatismale recevaient des comprimés soit de chloroquine, soit d'une substance inerte. On commença l'essai dans trois centres hospitaliers sur un total de 107 malades; 53 d'entre eux recevaient de la chloroquine et 54 la substance inerte. La dose de sulfate de chloroquine fut de $\mathbf{4 0 0} \mathrm{mg}$. par jour. En même temps, tous les malades recevaient à peu près $2,7 \mathrm{~g}$. d'aspirine par jour et toute physiothérapie nécessaire.

Pour des raisons diverses on retira de l'essai 25 malades dont 14 du groupe témoin et 11 du groupe traité. Des effets secondaires furent responsables de 5 cas retirés du groupe traité et de 4 cas du groupe témoin. Trois cas dans le groupe témoin subirent une telle détérioration, qu'on était obligé de les retirer de l'essai.

Pour compléter l'année expérimentale il resta donc 40 malades dans le groupe témoin et 42 dans le groupe traité par la chloroquine.

Les malades qui reçurent et tolérèrent la chloroquine accusèrent une amélioration statistiquement significative en ce qui concerne les indices d'évaluation clinique et la vitesse de sédimentation globulaire. Le taux moyen d'hémoglobine demeura sans changer. Des réactions d'hémagglutination furent effectuées par de différentes méthodes pendant la période $\mathrm{d}$ essai, mais les changements notés indiquèrent une amélioration nette chez des malades du groupe traité par la chloroquine. Les résultats radiologiques ne furent pas soumis à l'analyse statistique, mais ils tendaient à montrer moins de déterioration dans la groupe traité.

Une amélioration générale définie survint dans 30 pour cent des 40 malades du groupe témoin et dans 80 pour cent des 42 malades qui avaient accompli un an de traitement par la chloroquine. Une aggravation de la symptomatologie fut observée en 25 pour cent des témoins et seulement en 5 pour cent des traités. Le sulfate de chloroquine à la dose administrée pendant un an s'avéra parfaitement sûr.

\section{Cloroquina en artritis reumatoide.-Ensayo a "doble disfraz" de tratamiento por un año Sumario}

Se describen los resultados de un ensayo a "doble disfraz" (double blind), en el que enfermos con artritis reumatoide 'recibieron unos cloroquina, otros pastillas inertes, apropiadamente disfrazadas. Entre los tres centros participantes en la prueba se reunieron 107 enfermos; 53 de ellos recibieron el medicamento y los otros 54 la substancia inerte. La dosis de sulfato de cloroquina fué $400 \mathrm{mg}$. diarios. Todos los enfermos recibieron al mismo tiempo aproximadamente $2,7 \mathrm{~g}$. diarios de aspirina y la adecuada fisioterapia.

Fueron retirados de la investigación por diversas causas 25 enfermos, 14 entre el grupo de control y 11 entre él que tomaba cloroquina. Efectos tóxicos fueron responsables de cinco casos retirados en el grupo tratado con cloroquina y de cuatro casos en él de control. Tres de los casos del grupo de control se agravaron tanto, que tuvieron que ser retirados de la investigación.

Quedaron, por tanto, 40 enfermos en el grupo de control y 42 en el grupo tratado con cloroquina, durante un año.

Los enfermos que recibieron y toleraron la cloroquina presentaron una mejoría estadísticamente significativa con respecto a los indicios de valoración clínica y velocidad de sedimentación eritrocitaria. No se apreci\& cambio alguno en el termino medio de la cifra de hemoglobina. Reacciones de hemaglutinación sê llevaron a cabo por diferentes métodos durante período de investigación; los cambios observados indicaron una clara mejoría en los pacientes del grupo que recibió cloroquina. Los datos radiológicos no fueron sometidos a anáisis estadístico, pero tendían a mostrar una progresión más lenta en el grupo tratado que en el grupo de control.

Mejoría general definida se presentó en el 30 por ciento de los 40 enfermos de control y en el 80 por ciento de los 42 que completaron un año de tratamiento con cloroquina. Una agravación de la sintomatología se observó en el 25 por ciento del grupo de control y solamente en el 5 por ciento del grupo en tratamiento. El sulfato de cloroquina a la dosis administrada, durante un año, demostró ser perfectamente seguro. 